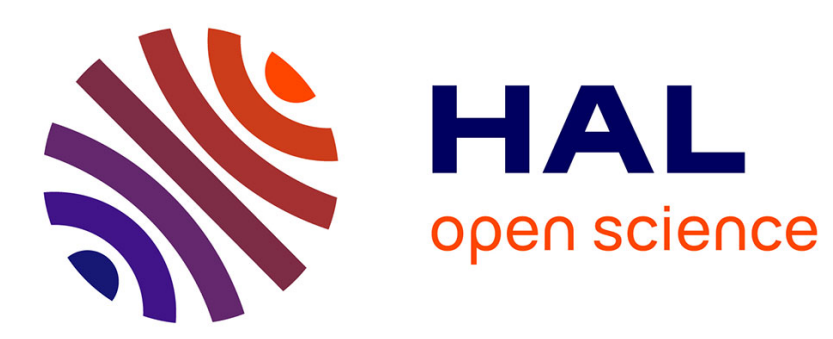

\title{
How to identify competence from interactions
}

Hocine Merzouki, Nada Matta, Hassan Atifi

\section{To cite this version:}

Hocine Merzouki, Nada Matta, Hassan Atifi. How to identify competence from interactions. SITIS 2019 - The 15th International Conference on Signal Image Technology \& Internet based Systems, Nov 2019, Torrente, Italy. 10.1109/SITIS.2019.00101 . hal-02399168

\section{HAL Id: hal-02399168 \\ https://hal-utt.archives-ouvertes.fr/hal-02399168}

Submitted on 8 Dec 2019

HAL is a multi-disciplinary open access archive for the deposit and dissemination of scientific research documents, whether they are published or not. The documents may come from teaching and research institutions in France or abroad, or from public or private research centers.
L'archive ouverte pluridisciplinaire HAL, est destinée au dépôt et à la diffusion de documents scientifiques de niveau recherche, publiés ou non, émanant des établissements d'enseignement et de recherche français ou étrangers, des laboratoires publics ou privés. 


\section{How to Identify competence from interactions}

\author{
Hocine Merzouki \\ ICD/TECH-CICO \\ Universty of Technology of Troyes \\ Troyes, France \\ hocine.merzouki@utt.fr
}

\author{
Nada Matta \\ ICD/TECH-CICO \\ Universty of Technology of Troyes \\ Troyes, France \\ nada.matta@utt.fr
}

\author{
Hassan Atifi \\ ICD/TECH-CICO \\ Universty of Technology of Troyes \\ Troyes, France \\ hassan.atifi@utt.fr
}

\begin{abstract}
The concept of competence generally refers to the knowledge, experiences, skills, attitudes, abilities and behavior that enable effective action in a work environment. Since knowledge is linked to action, the part of an individual's knowledge used and put to work every day, mixed with the organization's knowledge, characterizes the competencies that allow a group of people to make complex tasks. The knowledge resides primarily in the heads of beings. Interactions between these persons allow to observe their knowledge through different media as documents, meetings, telephone conversations, or computer communication networks. Many works focusing on the analyze of mediated interactions to different purposes exist. So, we use these works to propose a methodology of identifying competence in professional mediated communications exchanges.
\end{abstract}

Keywords- knowledge, competence, ability, behavior, interaction, mediated communications exchanges.

\section{INTRODUCTION}

The definition of competence depends highly of the discipline (sociology, psychology, management) as stated in [1, $2]$. However, the concept of competence generally refers to the knowledge, experiences, skills, attitudes, abilities and behavior that enable effective action in a work environment. Since knowledge is linked to action, the part of an individual's knowledge used and put to work every day, mixed with the organization's knowledge, characterizes the competencies that allow a group of people to make complex tasks [3]. According to Grundstein [3], the knowledge resides primarily in the heads of persons, and in the interactions between them. They exchange and combine their knowledge through media as documents, meetings, telephone conversations, or communication networks, so as to create new knowledge.

Many works focusing on the analyze of mediated interactions to different purposes exist $[5,6,7,8,9,10,11,12,13]$. Techniques like natural languages processing and pragmalinguistics are used in order to identify communication' actors intention knowledge and roles. We propose in this work to study some of these techniques in order to identify competence in professional mediated communications exchanges.

In this paper we present first of all the research problem and the objectives outline of our thesis, and then we describe the state of the art concerning the competence notion and communications analysis, to finally adopt a definition of competence, and its components' characterization. The methodology proposed is described in section 6 followed by the expected outcome of the application of our methodology, the stage of the research and a conclusion.

\section{RESEARCH PROBLEM}

In order to overcome the biases arising from static documentation and individual visions, the use of the traceability of information and events, that have supported a cooperative activity, can not only record the relationships between the elements of a cooperative activity, but more importantly, it is able to restore the evolution pattern of events that led to make a decision or to solve a problem.

To do this, it is necessary to analyze the interactions, especially digital ones, between the various actors in order to detect the interventions made, the roles played and the skills mobilized by them during problem solving or decision making processes.

These interventions and roles underpinned by competences put forward to achieve the assigned objectives, led us to tackle the following research problem: How to identify competence by analyzing computer mediated communications?

\section{OUTLINE OF OBJECTIVES}

The treatment of the problematic thus posed is based first of all on the definition and characterization of the concept of competence. Indeed, the literature identifies many meanings of this concept of competence. Some of them are specifically related to the notion of knowledge, others extend to more elements such as behavior, environment or performance; hence the first research question: What are the characteristics of the competence?

Once defined, the elements or components of the competence must be identifiable within an electronic communication in the case of this work. Indeed, we assume that a speaker in an interaction will make arguments, proposals and decisions based on his own competences.

From this perspective, it is necessary to analyze language or communication acts and to identify those that refer to or report on a competence; hence the second research question: What are the elements of language that make it possible to qualify as competent, a speaker in a communication?

The answer to these two questions makes it possible to highlight the components of competence, on the one hand, and their emanation through the speech acts, on the other hand. It remains to put them in link and to identify competence in professional mediated communications exchanges.

\section{RELATED WORKS}

The literature review focuses on two distinct parts. The first one deals with the concept of competence and the second one concerns the analysis of computer mediated communications. 


\section{A. Competences}

The literature review identifies many definitions of the concept of competence. Some are more specifically related to the notion of knowledge, others relate to resources and assets.

Durand [15] proposed several distinctions of the notion of competence, of which we cite the duality of explicit knowledge / tacit knowledge, individual knowledge / collective knowledge and cognitive versus behavioral knowledge. He borrows from educational research work the three key dimensions of individual learning which are knowledge, practice (know-how) and attitudes. Pestalozzi speaks of head (know), hard (know-how) and heart (attitudes) [16].

According to Paquette [17], competency is based on the relationship between specific knowledge in a given field of application and generic skills. Skills are statements that a person, and more generally a resource, can demonstrate the application of a generic skill to some knowledge, with some degree of performance.

Bourse, Harzallah, Leclère and Trichet [18] defined the competence as the "effect of combining and putting into play its resources (knowledge, know-how and behaviour) in a given context to achieve a goal or fulfil a specified mission".

Triaa [13] focused on the competence that are most used in industrial enterprises. According to this author, being competent, requires (i) to combine, in a relevant way, the personal resources (knowledge and know-how) and those of the environment (technological, material,...), (ii) to manage varied professional situations in order to achieve an objective according to criteria of realization and (iii) to provide a deliverable (tangible or intangible) for a recipient (customers, service provider, etc.) that makes it possible to evaluate a performance. Bonjour, Dulmet and Lhote [20] consider the competence as "the mobilization and dynamic organization of a set of heterogeneous cognitive resources that leads to the production of an acknowledged performance in the framework of a finalized activity and a particular class of situations".

According to these authors, thanks to his competence, an actor transforms a mission, with which he has been entrusted, into a successful flow of actions that will achieve expected results. Belkadi [21] retained this definition also. For Boumane, Talbi and Tahon [22], the "Competence is the ability of a person (actor) to act and react with the relevance required to perform an activity in a work situation". The actor is at the heart of a process that consists of selecting, combining and mobilizing knowledge, skills, abilities and behaviors on the one hand, and environmental resources on the other, in order to 'accomplish a mission defined by the company.

Monticolo [1] stated that in the design process, the actors use several skills to carry out the business activities. He borrowed the definition of competence established by Le Bortef [23], who considers it at the individual level as follows: "competence is the capacity for an individual to apply his knowledge and enhance his know-how in a professional setting". Competence is thus considered by Monticolo [1] as an action that the actor is able to achieve using one or more of his knowledge. Thus, he takes into account, in the organizational model, the concept of competence associated with the role.
We can note the several dimensions to be considered to represent competence. Section V. details these aspects.

\section{B. Communications analysis}

The concept of communication is considered in its interactional sense. Indeed, the traditional definition of the communication developed by Shannon [24] representing it as the transfer of a message from a source to a destination in the form of a signal is replaced from the early 1960 s by an interactional vision, where communication is neither a simple one-way transmission of a message, nor simply verbal and informational, nor context free [25].

In the analysis of communications, it is often useful to determine the intentions behind each message exchange [9]. As part of our work, we are particularly interested in computer-mediated communications. The literature review related to this issue revealed a number of works on e-mail, chats, and discussion forums.

Balog and De Rijke [7] developed methods for finding experts and their contact details using e-mail messages. They locate messages on a topic and then find the associated experts. They use an unsupervised approach where both the list of potential experts and their personal details are obtained automatically from e-mail message headers and signatures, respectively.

Dredze, Lau and Kushmerick [8] dealt with the issue of automatic classification of e-mails according to the activities related to them. Their approach is based on two characteristics of the activities: (i) the observation that activities connect groups of people and (ii) the observation that e-mails related to a given activity tend to focus on one or more topics. They presented several algorithms for automatically recognizing emails as part of ongoing activities by relying on the use of threads to determine the belonging of an email to a given activity.

According to Cohen, Carvalho and Mitchell [5], negotiation and delegation of shared tasks and subtasks are important uses of work-related e-mail. They used text classification methods to detect "email speech acts".

Guided by analysis of several email corpora and based on the ideas from Speech Act Theory developed by Searle [26], they defined a set of "email acts" (e.g., Request, Deliver, Propose, Commit) and then classified emails as containing or not a specific act by using machine learning algorithms.

A taxonomy of speech acts (verbs and nouns) applied to email communication (e-mail acts) is described and motivated Cohen [5]. It is summarized in Figure 1 below.

For Carvalho and Cohen [9], using only simple words as features, will lead to neglect a very important linguistic aspect, namely the textual context. For instance, the specific sequence "would you give me" can be more informative to detect a request act than the words "would", "you", "give" and "me" separately. In this order of ideas, they focused on analyzing the n-grams features extracted from e-mail communications. 


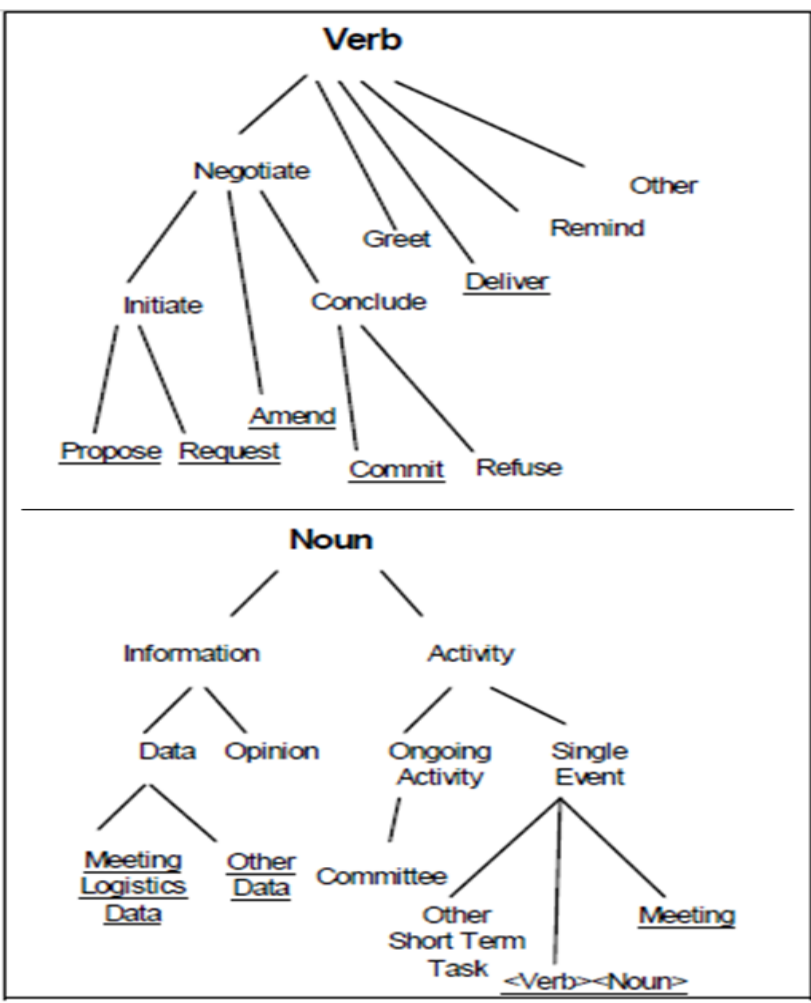

Fig. 1. Taxonomy of e-mail acts [5].

Khoussainov and Kushmerick [6] focused on identifying relations between messages for grouping emails into tasks. They used pair-wise message similarity to find potentially related messages, and hierarchical agglomerative clustering to group them into tasks. In addition to the textual similarity between messages, they extended the message similarity function to take into account the structured information available in e-mails, such as send dates, and message subjects. They investigated how (i) features of related messages in the same task can assist with classification of email speech acts, and how (ii) information about message speech acts can assist with finding related messages and grouping them into tasks.

Kalia, Motahari, Bartolini and Singh [12] presented an approach based on techniques from natural language processing and machine learning domains to automatically identify tasks and commitment creation, delegation, completion, and cancellation in email and chat conversations.

Their approach is based on Searle's [26,27] works in Speech Acts field that classified illocutionary acts into five classes. A message is classified as (i) commisive, if the sender of the message promises to take an action in the future, (ii) directive, when the speaker intends the receiver to do something, (iii) representative, if the sender commits to the truthfulness of the message, (iv) expressive, when the sender expresses his or her psychological state, (v) declaration, when the sender of the message brings about a change in status of the referred object (Kalia et al. 2013).

Rauscher, Matta, and Atifi [28] proposed to used request speech acts in order to identify problem solving knowledge from professional e-mails. They link interaction analysis to problem context restitution.

The communications analysis approches described in this section is summarized in Table I.
TABLE I. Summary of communications analysis approaches

\begin{tabular}{|c|c|c|}
\hline reference & objective & method \\
\hline $\begin{array}{l}\text { Balog et al, } \\
2006[7]\end{array}$ & $\begin{array}{l}\text { Finding experts and their } \\
\text { contact details in emails }\end{array}$ & Unsupervised approach \\
\hline $\begin{array}{l}\text { Dredze et al, } \\
2006[8]\end{array}$ & $\begin{array}{l}\text { Automatic classification } \\
\text { of emails }\end{array}$ & \\
\hline $\begin{array}{l}\text { Cohen, } 2004 \\
{[5]}\end{array}$ & $\begin{array}{l}\text { Email speech acts } \\
\text { detection }\end{array}$ & $\begin{array}{l}\text { Machine learning \& } \\
\text { taxonomy }\end{array}$ \\
\hline $\begin{array}{l}\text { Carvalho } \\
2006[6]\end{array}$ & $\begin{array}{l}\text { Email speech acts de- } \\
\text { tection }\end{array}$ & $\begin{array}{l}\text { Machine learning \& } \\
\text { taxonomy }\end{array}$ \\
\hline $\begin{array}{l}\text { Khoussainov } \\
\text { et al. } 2005 \text { [6] }\end{array}$ & $\begin{array}{l}\text { Grouping emails into } \\
\text { tasks }\end{array}$ & \\
\hline $\begin{array}{l}\text { Kalia, et al, } \\
2013[12]\end{array}$ & $\begin{array}{l}\text { Identifying business } \\
\text { tasks and commitments } \\
\text { from email and Chat }\end{array}$ & $\begin{array}{l}\text { Machine learning \& } \\
\text { NLP techniques }\end{array}$ \\
\hline $\begin{array}{l}\text { Rauscher, et } \\
\text { al, [28] }\end{array}$ & $\begin{array}{l}\text { Identify problem solving } \\
\text { knowledge from } \\
\text { professional e-mails }\end{array}$ & \\
\hline
\end{tabular}

\section{COMPETENCE REPRESENTATION}

The literature review above allowed us to retain the following working definition of competency as : The combination and implementation of knowledge, know-how and know to behave and to achieve a recognized performance, in relation to a given environment and as part of a finalized activity.

\section{A. Components of competence}

Starting from the working definition above, we did a comparison, illustrated in Table II, with other definitions found in the literature review, in order to align the different components of the concept of competence.

The analysis of this comparison table reveals that the "Knowledge" and the "know-how" are mentioned in all the definitions. They are immutable components of the competence.

"Behaviour" is an important component of competence, even if it is not directly referenced in the case of apprenticeship [17], R\&D projects and Triaa [19] for the following reasons:

Concerning the definition of Paquette [17], who treated the competence concept in the framework of the apprenticeship, "Behaviour" is not clearly mentioned, however, it is grouped within the "know-how" notion under the common name of "generic skills".

Belkadi [21] uses the term of "ability" which is more associated with the "know-how" than the "behaviour".

Furthermore, the "behaviour" being rather a trait of character, is not supported in the apprenticeship.

Environment and activity are competency-related components, except in the area of learning [17], and this is because the learning process does not typically involve a particular activity and environment, except possibly in very specific trainings. In other words, the environment and activity are not excluded but rather transcended in learning.

Performance is integrated mainly in the industrial environment (process and work situation) for obvious reasons of competition. It is also in learning [17], as a differentiating element of learning levels and therefore, to determine the resources to be made available to the learner. 
TABLE II. Alignment of the definitions of the competence

\begin{tabular}{|l|c|c|c|c|c|c|}
\hline \multicolumn{1}{|c|}{$\begin{array}{c}\text { Refe- } \\
\text { rence }\end{array}$} & $\begin{array}{c}\text { Know- } \\
\text { ledge }\end{array}$ & $\begin{array}{c}\text { Know- } \\
\text { how }\end{array}$ & $\begin{array}{c}\text { Beha } \\
\text {-vior }\end{array}$ & $\begin{array}{c}\text { Perfor- } \\
\text { mance }\end{array}$ & $\begin{array}{c}\text { Envi- } \\
\text { ro- } \\
\text { nment }\end{array}$ & $\begin{array}{c}\text { Acti- } \\
\text { vity }\end{array}$ \\
\hline $\begin{array}{l}\text { Durand, } \\
\text { 1997 [15] }\end{array}$ & $\mathrm{X}$ & $\mathrm{X}$ & $\mathrm{X}$ & $\mathrm{X}$ \\
\hline $\begin{array}{l}\text { Bourse et } \\
\text { al, 2002 } \\
\text { [18] }\end{array}$ & $\mathrm{X}$ & $\mathrm{X}$ & $\mathrm{X}$ & $\mathrm{X}$ & $\mathrm{X}$ \\
\hline $\begin{array}{l}\text { Paquette, } \\
\text { 2007 [17] }\end{array}$ & $\mathrm{X}$ & $\mathrm{X}$ & $\mathrm{X}$ & $\mathrm{X}$ & $\mathrm{X}$ & $\mathrm{X}$ \\
\hline $\begin{array}{l}\text { Boumane } \\
\text { et al, 2006 } \\
\text { [22] }\end{array}$ & $\mathrm{X}$ & $\mathrm{X}$ & $\mathrm{X}$ & $\mathrm{X}$ & $\mathrm{X}$ & $\mathrm{X}$ \\
\hline $\begin{array}{l}\text { Bonjour } \\
\text { et al, 2002 } \\
\text { [20] }\end{array}$ & $\mathrm{X}$ & $\mathrm{X}$ & $\mathrm{X}$ & $\mathrm{X}$ & $\mathrm{X}$ & $\mathrm{X}$ \\
\hline $\begin{array}{l}\text { Triaa, } \\
\text { 2018 [19] }\end{array}$ & $\mathrm{X}$ & $\mathrm{X}$ & $\mathrm{X}$ & $\mathrm{X}$ & $\mathrm{X}$ \\
\hline $\begin{array}{l}\text { Belkadi, } \\
\text { 2006 [21] }\end{array}$ & $\mathrm{X}$ & $\mathrm{X}$ & & $\mathrm{X}$ & $\mathrm{X}$ \\
\hline $\begin{array}{l}\text { Monticolo } \\
\text { 2008 [1] }\end{array}$ & $\mathrm{X}$ & $\mathrm{X}$ & & $\mathrm{X}$ & $\mathrm{X}$ \\
\hline $\begin{array}{l}\text { Harzallah, } \\
\text { 2017 [2] }\end{array}$ & $\mathrm{X}$ & $\mathrm{X}$ & $\mathrm{X}$ & & & $\mathrm{X}$ \\
\hline
\end{tabular}

From the foregoing, we can systematize the use of the different components of the competence according to three points of view; the individual-centric vision, the industrycentric vision and organization-centric vision. The figure 2 below illustrates these different visions.

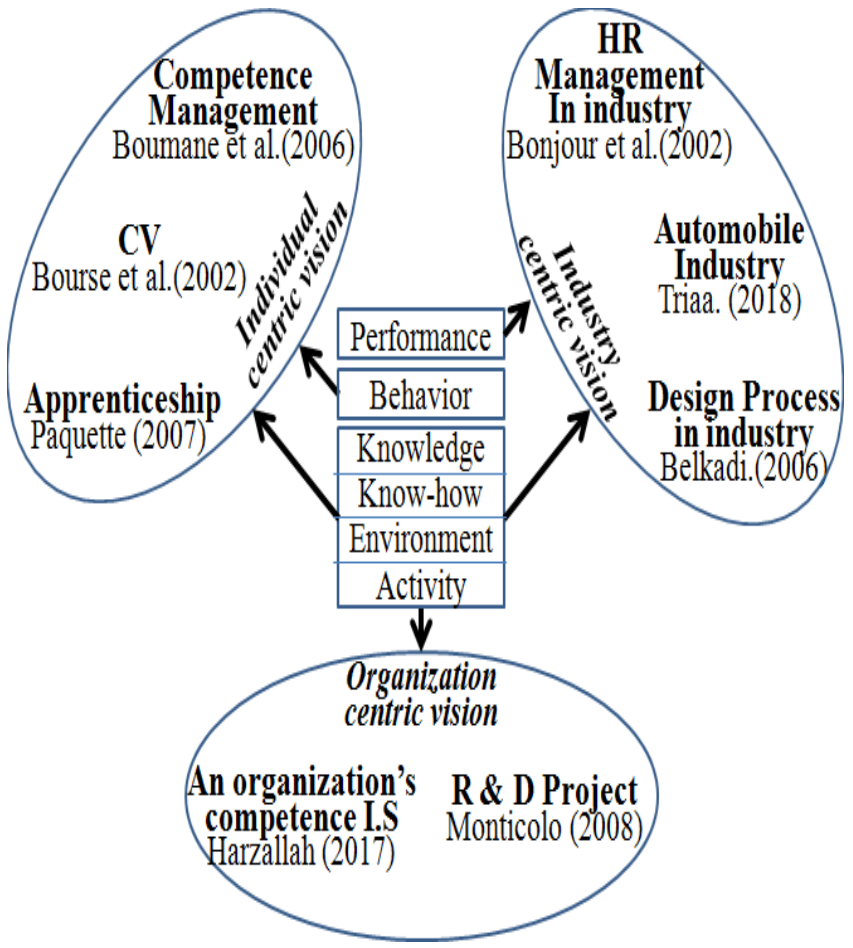

Fig. 2. Use of competence components according to different visions: competence, human resource and organizations management

\section{B. Characterization of competence components}

In this section, we propose a characterization of some components of the concept of competence, based on elements from a comparative analysis, under the terminological and pragmatic aspects, of three systems providing the skills and competences, namely the "European DIctionary of Skills and Competences" (E-DISCO), "Occupational Information Network" (O*Net) and "Taxonomy-DB" [29]. We choose to focus our characterization on three components of the competence: knowledge, Know-how and behavior. These components are characterized as summarized in the table III below.

TABLE III. Summary of communications analysis approaches

\begin{tabular}{|l|l|l|l|}
\hline & Knowledge & \multicolumn{1}{|c|}{ Know-how } & \multicolumn{1}{|c|}{ Behavior } \\
\hline $\begin{array}{l}\text { Charac- } \\
\text { terization }\end{array}$ & $\begin{array}{l}\text { Principles and } \\
\text { facts applying } \\
\text { in general } \\
\text { areas }\end{array}$ & $\begin{array}{l}\text { Developed } \\
\text { capabilities to } \\
\text { apply one's } \\
\text { experience or } \\
\text { knowledge in a } \\
\text { given art or job }\end{array}$ & $\begin{array}{l}\text { Attributes/ } \\
\text { characters of the } \\
\text { individual that } \\
\text { influence the } \\
\text { performance }\end{array}$ \\
\hline $\begin{array}{l}\text { Modes of } \\
\text { acquisition }\end{array}$ & $\begin{array}{l}\text { Learning } \\
\text { and/or } \\
\text { experience }\end{array}$ & $\begin{array}{l}\text { Experience and } \\
\text { develop-ment of } \\
\text { Capacities }\end{array}$ & $\begin{array}{l}\text { Intuition and } \\
\text { Experience }\end{array}$ \\
\hline $\begin{array}{l}\text { Expres- } \\
\text { sion mode }\end{array}$ & $\begin{array}{l}\text { Know }+ \\
\text { Name of } \\
\text { activity } \\
\text { domain }\end{array}$ & $\begin{array}{l}\text { Action Word }+ \\
\text { Object }+ \text { Context }\end{array}$ & $\begin{array}{l}\text { Be }+ \text { Adjective } \\
\text { or Have }+ \\
\text { Ability }\end{array}$ \\
\hline
\end{tabular}

\section{Methodology}

We propose in this section our approach which consists of identifying the components of the competence in professional mediated communications exchanges using a taxonomy applied to a corpus of electronic exchanges.

\section{A. Taxonomy}

The taxonomy we used in our approach is based on the "European dictionary of skills and competences" (E-DISCO) which is a comprehensive thesaurus of skills, personal attitudes, values, behavioral patterns and action verbs, available in fourteen European languages.E-DISCO was funded by the European Commission, Leonardo da Vinci program, and the Austrian Federal Ministry for Education, the Arts and Culture and its development took place between September 2004 and February 2008. E-DISCO aims to support European transparency tools [29].

E-DISCO is based on four comprehensive national skills compilations, namely ROME (France), Taxonomy-DB (Sweden), "Kompeten-zenkatalog" (Germany), and "AMSQualifikations-klassifikation" (Austria) [29].

We extracted from E-DISCO three lists namely activity domains, action verbs and abilities.

The list of domains summarized in table IV contains 25 main domains of activity. Each one is subdivided into several sub-domains and sub-sub-domains.

The Table $\mathrm{V}$ below contains the list of common action verbs identified in E-DISCO. These verbs applied, within an expression, to an object belonging to a given domain, refer to a potential know-how in that domain.

The list of abilities and skills is illustrated in Table VI. It's divided on four ability groups; physical, personal, cognitive and managerial abilities. 
TABLE IV. List of the activity domains from "E-DISCO" [29]

\begin{tabular}{|l|l|}
\hline \multicolumn{2}{|c|}{ Domains } \\
\hline - Agriculture, forestry and & - Law \\
fishery & - Life sciences \\
- Architecture and building & - Manufacturing and processing \\
- Arts & materials \\
- Business and & - Manufacturing and processing \\
- administration & of food \\
- Eomputing & - Mathematics and statistics \\
- Electrion & - Mechanical engineering \\
- Environmental protection & - Personal services \\
- Health & - Physical sciences \\
- Humanities & - Security services \\
- Journalism and & - Social and behavioural science \\
information & - Social services \\
- Transport services & \\
\hline
\end{tabular}

TABLE V. Common action verbs from "E-DISCO" [29]

\begin{tabular}{|c|}
\hline Action verbs \\
\hline \\
Adjust / Advise / Allocate / analyze / Anticipate / Apply / Apply tech- \\
niques / Approve / Assemble / Assess / Assist / Audit / Blend / Breed / \\
Budget / Build / Buy / Calculate / Calibrate / Care / Care for / Certify / \\
Check / Clean / Collaborate / Collect / Compare / Compile / Conclude / \\
Configure / Contact / Control / Coordinate / Counsel / Create / Cultivate \\
/ Cut / Cut up / Deal with / Decide / Define / Delegate / Deliver / \\
Demonstrate / Describe / Design / Detect / Develop / Diagnose / Dig / \\
Direct / Disconnect / Dismantle / Display for sale / Disseminate / Dis- \\
solve / Draw something up / Draw up contracts / Drill / Eliminate / \\
Evaluate / Examine [...] \\
\end{tabular}

TABLE VI. List of abilities and skills from "E-DISCO" [29]

\begin{tabular}{|l|l|}
\hline \multicolumn{2}{|c|}{ Abilities and skills } \\
\hline $\begin{array}{l}\text { Physical } \\
\text { attributes } \\
\text { and } \\
\text { abilities }\end{array}$ & $\begin{array}{l}\text { Absence of allergies / Absence of perception defects / } \\
\text { Agility / Attractive Appearance / Dexterity / General } \\
\text { physical fitness / Physical strength / Responsiveness / } \\
\text { Sense of balance / Stamina / Sure-footedness / Tolerance of } \\
\text { cold, heat, noise [ . . . }\end{array}$ \\
\hline $\begin{array}{l}\text { Personal } \\
\text { skills and } \\
\text { abilities }\end{array}$ & $\begin{array}{l}\text { Ability to (work in a team, cooperate, support pressure) / } \\
\text { Absence of phobias / Assertiveness / Balanced personality / } \\
\text { Darefulness / Competitive / Courage / Credibility / }\end{array}$ \\
$\begin{array}{l}\text { Discretion / Empathy / Enthusiasm / Flexibility / } \\
\text { Friendliness / Honesty / Hygiene / Independence / } \\
\text { Onvention / Judgement / Loyalty / Open-mindedness / } \\
\text { Originality [. . .] }\end{array}$ \\
\hline $\begin{array}{l}\text { Cognitive } \\
\text { skills and } \\
\text { problem } \\
\text { solving } \\
\text { ability }\end{array}$ & $\begin{array}{l}\text { Ability to (concentrate, learn) / Analytical thinking / } \\
\text { Application of laws, regulations and guidelines / } \\
\text { Application of professional techniques / Being good with } \\
\text { figures / General technical skills / Information gathering / } \\
\text { Intellectual curiosity / Inventiveness [. . .] }\end{array}$ \\
\hline $\begin{array}{l}\text { Manageri } \\
\text { al and } \\
\text { organisati } \\
\text { onal skills }\end{array}$ & $\begin{array}{l}\text { Ability to (coordinate, organize oneself) / Capable of } \\
\text { multitasking / Decision-making / Entrepreneurial thinking / } \\
\text { Leadership skills / Management of (personnel, financial, } \\
\text { and material resources, time, activities, techniques) [ . . . }\end{array}$ \\
\hline
\end{tabular}

\section{B. Corpus}

The question of the corpus of electronic exchanges to choose and on which will be applied our methodology is discussed on two aspects. The first concerns the nature of the corpus, which can consist of exchanges of e-mail or communications within a forum or chat. The second concerns the source of the corpus. It can be constituted by electronic communications within a professional organization, as it can be issued from exchanges in a community of interest or in the context of a project management. Depending on the nature and the source of the corpus, the competence notion may be expressed in an implicit or explicit manner.

Indeed, we suppose, for instance, that an interaction within a professional organization as in the framework of a project is marked by the hierarchical position of the interlocutors and also their competences can be explicitly mentioned or solicited during the exchanges. Conversely, in exchanges within communities of interest, there is no notion of hierarchy; the interlocutors often don't decline even their identity. As a result, identifying competencies in this kind of exchange may be less obvious.

Two extracts from Ubuntu corpus and Enron corpus showing the complexity of the approach are illustrated respectively in table VII and table VIII below.

TABLE VII. An extract from Ubuntu corpus

\begin{tabular}{|c|c|l|}
\hline From & To & \multicolumn{1}{|c|}{ Text } \\
\hline A & B & $\begin{array}{l}, \text { :S I thought that's what you were doing @.... @ow did you start gparted? from the menu on the } \\
\text { on... } \\
\text { live cd or did you run the install? }\end{array}$ \\
\hline B & A & $\begin{array}{l}\text { I'm going to reboot again, but into my root partition and } \\
\text { save my files to the ext hdd then start the process. } \\
\text { Thanks for your help again. I had to install gparted from } \\
\text { synaptic. }\end{array}$ \\
\hline A & B & on the live cd? \\
\hline B & A & yes, on the CD. \\
\hline A & B & gparted should of already been in the menu on the cd \\
\hline
\end{tabular}

TABLE VIII. An extract from Enron corpus

\begin{tabular}{|c|c|l|}
\hline From & To & \multicolumn{1}{c|}{ Text } \\
\hline A & B & $\begin{array}{l}\text { Once you make the changes to the release, please fax a } \\
\text { copy to Kevin Kolb. I am going to try and meet Pauline } \\
\text { Kuo on Tuesday or Wednesday to wrap things up. In } \\
\text { addition to the release, I will need the guarantee and a } \\
\text { release of lien for the smaller note. I will speak to you } \\
\text { on Monday. Hope things are going well with your wife.. }\end{array}$ \\
\hline B & A & $\begin{array}{l}\text { Thanks for the info. The changes are alright. I will make } \\
\text { the revisions and call you. I am at MD Anderson } \\
\text { tomorrow morning, so it will probably be late tomorrow } \\
\text { or over the weekend. We will coordinate Monday } \\
\text { morning so I can get you everything you need for the } \\
\text { closing. Thanks. }\end{array}$ \\
\hline
\end{tabular}

\section{Identifying competences methodology}

Our methodology is based on the analysis of computed mediated communication corpus by developing, in one hand, a pragmatic analysis grid in order to find the intention of the interlocutor through the identification of speech acts used. This analysis based on pragmatics will allow us to identify the intention of the speaker according to Searl's [26,27] classification of speech acts. The aim of this step is to know if the interlocutor intention is commisive, directive, representative, expressive or declarative.

For instance, when a speaker declares "I will assemble a list of ENA contracts..." that represents a commisive intention and when he says "yes, on the CD.", that corresponds to 
a representative intention. It is precisely for this purpose that the pragmatic analysis grid is used.

In the other hand, our approach is based on a taxonomy of activity domains, action verbs and abilities, extracted from E-DISCO taxonomy (available on http://disco-tools.eu/ disco2 portal). The application of this taxonomy will lead us to identify respectively knowledge, know-how and behavior as components of competence invoked in exchanges between interlocutors. For instance, do they put forward information skills (knowledge), practical skills (know-how) or relational skills (behavior). And above all, how do these different skills appear in the communication exchanges?

The identification of a competence is based, according to our approach, on the matching between the intention of the speaker, the action verb related to his intention and the nouns identified within his message, which nouns may belong to a specific domain glossary.

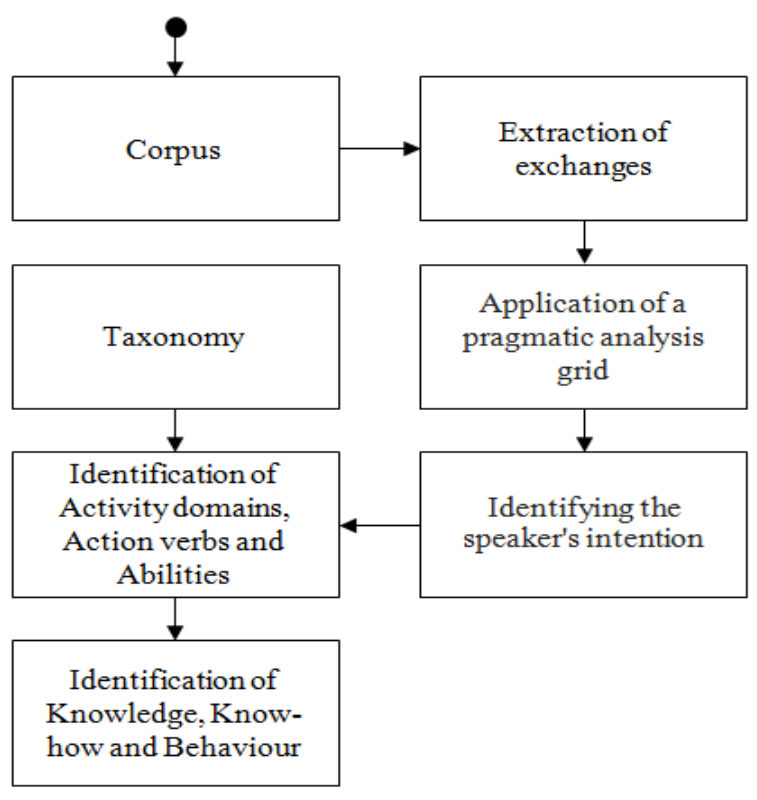

Fig. 3. Methodology of competence identification

Our approach in based on natural language processing (NLP) and fellows the main steps described below:

$\Rightarrow$ Identifying action verbs related to taxonomy

$\Rightarrow$ Isolating messages containing action verbs, by extracting the thread of related interaction

$\Rightarrow$ If action verb belongs to a specific domain

$\Rightarrow$ Qualifying competences based on domain glossary

$\Rightarrow$ Applying specific pragma-linguistics grid in order to qualify the "know-how" and the "knowledge" related to the corresponding domain

$\Rightarrow$ Else

$\Rightarrow$ Applying specific pragma-linguistics grid to qualify the "know to behave" related to the corresponding ability

$\Rightarrow$ End if

$\Rightarrow$ Qualify the competence composed of "knowledge", "know-how" and "know to behave"

\section{EXPECTED OUTCOME}

As described above, the proposed approach based on the decomposition of the concept of competence and the use of a rich taxonomy will identify the competences highlighted through the analysis of electronic exchanges. Specific Pragma-linguistics grids will be also defined related to each competence components.

Applying our approach to corpora from different sources and natures will allow us to compare the relevance of the identification of the competence components according to these criteria.

\section{STAGE OF THE RESEARCH}

At the current stage of our work, the research conducted to select a corpus of electronic communications has allowed us to locate two corpora. The first one is the UBUNTU email, chat and forum corpus issued from the community of the same name [30]. It is a problem-solving support platform dealing exclusively with information technology issues. The second one is the ENRON corpus containing more than 250,000 emails exchanged by the employees of Enron Company. The latter being an international oil company, its corpus contains a rich variety of subjects.

Presently, we are focusing on defining the pragmatic analysis grid to be applied to the corpus identified so far.

\section{FIRST RESULTS}

As a first step of our methodology, we conducted the experiment consisting on searching the apparition frequency of action verbs in a set of emails selected from each corpus.

The results obtained are illustrated in table IX. They show that almost all the action verbs contained in the EDISCO taxonomy appear in the Enron corpus, comparatively with the Ubuntu corpus where only a few action verbs appear.

Enron's corpus illustrates the activity of an oil company, but even though it is specialized in this specific area, Enron, as a large organization, has other activities such as those related to management, finance and human resources; which involves dialogues covering a wide range of action verbs

TABLE IX. Apparition frequency of action verbs in Enron and Ubuntu corpuses.

\begin{tabular}{|l|c|c|l|c|c|}
\hline $\begin{array}{c}\text { Action } \\
\text { verbs }\end{array}$ & $\begin{array}{c}\text { Enron } \\
\text { corpus }\end{array}$ & $\begin{array}{c}\text { Ub- } \\
\text { un- } \\
\text { tucor- } \\
\text { pus }\end{array}$ & $\begin{array}{c}\text { Action } \\
\text { verbs }\end{array}$ & $\begin{array}{c}\text { Enron } \\
\text { corpus }\end{array}$ & $\begin{array}{c}\text { Ubuntu } \\
\text { corpus }\end{array}$ \\
\hline adjust & 319 & & compare & 426 & \\
\hline advise & 125 & & compile & 266 & 319 \\
\hline allocate & 163 & & conclude & 223 & \\
\hline analyse & 250 & 175 & configure & 46 & 234 \\
\hline anticipate & 277 & & contact & 3413 & \\
\hline apply & 448 & & control & 1301 & \\
\hline approve & 1053 & & coordinate & 250 & \\
\hline assemble & 57 & & counsel & 1931 & \\
\hline monitor & 504 & & create & 1010 & \\
\hline assess & 379 & & cultivate & & \\
\hline
\end{tabular}


The explanation of the result showing a few action verbs appearing in the Ubuntu corpus is based on the fact that this corpus concerns a community which deals with IT issues. A research in the glossary related to this domain shows that verbs such as analyze, configure and compile belong to the IT glossary. Some messages extracted from the Ubuntu corpus and Enron corpus are illustrated respectively in table $\mathrm{X}$ and table XI.

TABLE X. Set of messages from Ubuntu corpus

\begin{tabular}{|l|l|}
\hline \multirow{3}{*}{ Action verbs } & \multicolumn{1}{c|}{ Messages } \\
\hline \multirow{3}{*}{ install } & $\begin{array}{l}\text { Although the .mpg files are responding to the media } \\
\text { software I have installed unlike it did before all of this. }\end{array}$ \\
\cline { 2 - 3 } format & $\begin{array}{l}\text { Yeah I'll just do that. Put everything on ext hdd and } \\
\text { start from scratch and re-install Ubuntu. }\end{array}$ \\
\hline reboot & $\begin{array}{l}\text { I'm going to reboot again, but into my root partition } \\
\text { and save my files to the ext hdd then start the process. } \\
\text { Thanks for your help again. }\end{array}$ \\
\cline { 2 - 3 } & $\begin{array}{l}\text { I'm going to go ahead and put in the installation CD } \\
\text { and reboot. And gparted will still be available when I } \\
\text { boot from the CD so I can do the partitioning? }\end{array}$ \\
\hline $\begin{array}{l}\text { If it's going to be used for linux you want to format it } \\
\text { as ext3 type } \\
\text { ubuntu? }\end{array}$ \\
\hline
\end{tabular}

TABLE XI. Set of messages from Enron corpus

\begin{tabular}{|c|c|}
\hline Action verbs & Message \\
\hline \multirow{2}{*}{ assemble } & $\begin{array}{l}\text { Assemble the pricing of a transaction from a } \\
\text { benchmark price curve. }\end{array}$ \\
\hline & $\begin{array}{l}\text { Patrick, I will assemble a list of ENA contracts that } \\
\text { contributed to the financials that were presented in the } \\
\text { data room. }\end{array}$ \\
\hline \multirow{2}{*}{ monitor } & $\begin{array}{l}\text { Please monitor local news and weather forecasts and } \\
\text { use your judgement to insure a safe commute. }\end{array}$ \\
\hline & $\begin{array}{l}\text { I monitor and I am responsible for representing my } \\
\text { company in FERC and state regulatory proceedings. }\end{array}$ \\
\hline \multirow{2}{*}{ examine } & $\begin{array}{l}\text { The court examined the three exceptions to the general } \\
\text { rule. }\end{array}$ \\
\hline & $\begin{array}{l}\text { We will examine the foundation stone that underpins } \\
\text { the vast majority of credit. }\end{array}$ \\
\hline
\end{tabular}

\section{CONCLUSION}

The research conducted as part of our work has led us to study the notion of competence and to retain a work definition while identifying its components. Three dimensions are putted on related to individual, industrial and organizational point of views in order to answer our first research question.

An overview of the existing taxonomies led us to choose action verbs and classify criteria. These criteria can help to isolate interactions related to competences. First steps of a methodology have been defined towards the identification of competences from computer-mediated communications.

In order to answer our third research question, two corpora were also chosen according to different modalities and sources. First findings of applying the methodology encourage us to complete it and to identify specific pragmalinguistics corresponding to competence components.

Studying thread interactions will help to qualify the nature of the competences. We aim at testing this hypothesis firstly on the identifying corpus and then on other ones from community of practices and dedicated social networks.

\section{REFERENCES}

[1] D. Monticolo. Une approche organisationnelle pour la conception d'un système de gestion des connaissances fondé sur le paradigme agent. Thèse de Doctorat Informatique. Université de Technologie de Belfort Montbéliard, 2008.

[2] M. Harzallah. Contributions à l'Ingénierie des Connaissances : Construction et Validation d'Ontologie et Mesures Sémantique. Informatique [cs]. Université de Nantes, Ecole Polytechnique, 2017.

[3] M. Grundstein. From capitalizing on company knowledge to knowledge management. Knowledge management, classic and contemporary works, 12, 261-287, 2000.

[4] M. Grundstein. Assessing enterprise's knowledge management maturity level. In World Summit on Knowledge Society (pp. 380-387). Springer, Berlin, Heidelberg, 2008.

[5] W. W. Cohen, V. R. Carvalho and T. M. Mitchell. Learning to Classify Email into Speech Acts. In Proceedings of the 2004 Conference on Empirical Methods in Natural Language Processing, p. 309-316, Barcelona, Spain.

[6] R. Khoussainov and N. Kushmerick. Email task management: An iterative relational learning approach. CEAS, 2005.

[7] K. Balog, M. De Rijke. Finding Experts and their Details in Email Corpus. University of Amsterdam Kruislaan 403, 1098 SJ Amsterdam, 2006.

[8] T. Dredze, N. Lau and N. Kushmerick. Automatically classifying emails into activities. In Proceedings of the 11th international conference on Intelligent user interfaces (pp. 70-77). ACM, 2006.

[9] V. R. Carvalho and W. Cohen. Improving "Email Speech Acts" Analysis via N-gram Selection. Carnegie Mellon University, 2006.

[10] N. Matta, H. Atifi, M. Sediri and M. Sagdal. Analysis of interactions on coordination for design projects. In 2010 Sixth International Conference on Signal-Image Technology and Internet Based Systems (pp. 344-347). IEEE, 2010.

[11] N. Matta, K. Sidoumou, G. Ninova and H. Atifi. Modèlisation d'une analyse pragma-linguistique d'un forum de discussion. arXiv preprint arXiv:1008.4310, 2010.

[12] A. Kalia, N. Motahari, C. Bartolini and M. Singh. Identifying Business Tasks and Commitments from Email and Chat Conversations. In HP Labs Technical Report, 2013.

[13] M. Tavafi, Y. Mehdad, S. Joty and G. Carenini. Dialogue act recognition in synchronous and asynchronous conversations. Proceedings of the SIGDIAL 2013 Conference, pages 117-121. Metz, France.

[14] F. Rauscher, N. Matta and H. Atifi. KTR: an approach that supports Knowledge extraction from design interactions. IFAC-PapersOnLine, 49(12), 473-478, 2016.

[15] T. Durand. Repenser les compétences de l'entreprise. maxime.moulins.free.fr. Professeur, Ecole Centrale Paris, 1997. 
[16] A. Brühlmeier. Head, heart and hand: Education in the spirit of Pestalozzi. Open Book Publishers, 2010.

[17] G. Paquette. An ontology and a software framework for competency modeling and management. Educational Technology \& Society, 10 (3), 1-21, 2007

[18] M. Bourse, M. Harzallah, M. Leclère and F. Trichet. CommOnCV: modeling the competencies underlying a Curriculum Vitae. In Proceedings of the 14th international conference on Software Engineering and Knowledge Engineering 2002, (pp. 65-73).

[19] W. Triaa. Gestion agile de processus métier: proposition d'une approche tirée par les compétences (Doctoral dissertation). University of grenoble alpes, France, 2018.

[20] E. Bonjour, M. Dulmet and F. Lhote. An internal modeling of competency, based on a systemic approach, with socio-technical systems management in view. In Proc. of IEEE International Conference on Systems, Man and Cybernetics. SMC. 2002. p. 6-9.

[21] F. Belkadi. Contribution au pilotage des compétences dans les activités de conception : de la modélisation des situations à la caractérisation des compétences. Doctoral thesis Automatic / Robotic. University of Franche-Compté, 2006.

[22] A. Boumane, A. Talbi and A. Tahon. Contribution à la modélisation de la compétence. In MOSIM Conference, 2006.

[23] G. Le Boterf. Construire les compétences individuelles et collectives: Le modèle: agir avec compétence en situation. Editions Eyrolles 2013.
[24] C. E. Shannon. A mathematical theory of communication. Bell system technical journal, 1948, vol. 27, no 3, p. 379-423.

[25] N. Matta, H. Atifi, G. Ducellier. Daily knowledge valuation in organizations: : Traceability and Capitalization. ISTE Ltd and John Wiley \& Sons Inc, 2016.

[26] J. R Searl. The classification of illocutionary acts. Language and Society N, 5, 1-24, 1976.

[27] J. R. Searl. Speech Acts, London: Cambridge University Press, 1969.

[28] F. Rauscher, N. Matta and H. Atifi. Discovering Problem-Solving Knowledge in Business Emails, Traceability in Software Design using Computer Mediated Communication, in IC3K, Knowledge Management and Information System Conferences, Rome, Octobre, 2014.

[29] J. Markowitsch and C. Plaimauer. Descriptors for competence: towards an international standard classification for skills and competences. Journal of European Industrial Training, 33(8/9), 817837, 2009.

[30] S. Salim, N. Hernandez and E. Morin. Comparaison d'approches de classification automatique des actes de dialogue dans un corpus de conversations écrites en ligne sur différentes modalités. Actes de la conférence conjointe JEP-TALN-RECITAL, volume 2 : TALN 201. 